\title{
A mutated retinoic acid receptor- $\alpha$ exhibiting dominant-negative activity alters the lineage development of a multipotent hematopoietic cell line
}

\author{
Schickwann Tsai, ${ }^{1}$ Stephen Bartelmez, ${ }^{1}$ Richard Heyman, ${ }^{2}$ Klaus Damm, ${ }^{3}$ Ronald Evans, ${ }^{3}$ \\ and Steven J. Collins ${ }^{1}$ \\ ${ }^{1}$ Program in Molecular Medicine, Fred Hutchinson Cancer Research Center, Seattle, Washington 98104 USA; ${ }^{2}$ Ligand \\ Pharmaceuticals, San Diego, California 92121 USA $^{3}$ The Salk Institute for Biological Studies, Howard Hughes \\ Medical Institute, La Jolla, California 92037 USA
}

The retinoic acid receptor (RAR $\alpha)$ is expressed in virtually all hematopoietic lineages, but the role of this transcription factor in regulating the growth and differentiation of hematopoietic progenitors is unknown. We have constructed a mutant RAR $\alpha$ that both exhibits dominant-negative activity against the normal RAR $\alpha$ in transient expression assays in mouse fibroblasts and inhibits retinoic acid-induced neutrophilic differentiation of the HL-60 human promyelocytic leukemia cell line. When this dominant-negative RARa construct is introduced into the multipotent interleukin-3-dependent FDCP mix A4 murine hematopoietic cell line, there is a rapid switch from spontaneous neutrophil/monocyte differentiation to basophil/mast cell development. Thus, in this multipotent hemopoietic cell line the normal RAR $\alpha$ transcription factor and/or related molecules appear to promote the differentiation of neutrophils and monocytes but suppress the development of basophils/mast cells.

[Key Words: RAR $\boldsymbol{\alpha}$; hemopoietic differentiation; transcription factor; dominant-negative activity; transient expression assay]

Received May 18, 1992; revised version accepted September 17, 1992.

Retinoic acid (RA), the natural acidic derivative of vitamin A (retinol), is a critical molecule regulating growth and differentiation of a wide variety of cells. RA is centrally involved in epithelial differentiation (Lotan 1980), plays a critical role as a tissue-specific morphogen during embryogenesis (Thaller and Eichele 1987), and suppresses malignant transformation of epithelial cells both in vitro (Merriman and Bertam 1979) and in vivo (Hong et al. 1990). These diverse and complex biologic effects of RA are mediated through a number of closely related nuclear RA receptors (RARs) that are members of the steroid/thyroid hormone receptor superfamily and possess discrete DNA-binding and RA (ligand)-binding domains (Evans 1988).

The expression of RARs is widespread, with RAR mRNA noted in most fetal and adult tissue (Zelent et al. 1989). Unlike the steroid hormone receptors, the RA receptors, as well as thyroid hormone receptors, appear to be associated with chromatin and may be constitutively bound to cis-acting regulatory sequences in the absence of ligand (Lavin et al. 1988; Damm et al. 1989). Thus, these receptors may have different regulatory roles in the absence and presence of ligand.

Several lines of indirect evidence suggest that RA and
RARs may be involved in regulating the development of hematopoietic progenitors. For example, RAR mRNA (predominantly RAR $\alpha$ ) is widely expressed in different hematopoietic cell types (Gallagher et al. 1989; de The et al. 1989; Largman et al. 1989). Treatment of a human myeloid leukemia cell line HL-60 with all-trans RA (ATRA) induces these cells to undergo terminal neutrophilic differentiation, and this induction is directly mediated through RAR $\alpha$ (Breitman et al. 1980; Collins et al. 1990). In addition, human acute promyelocytic leukemia (APL) exhibits a specific $15 ; 17$ chromosome translocation involving RAR $\alpha$, which presumably results in the disruption of a normal, albeit unknown, regulatory function of this particular RAR (Borrow et al. 1990; de The et al. 1990b, 1991; Alcalay et al. 1991; Kakizuka et al. 1991). Furthermore, ATRA induces the leukemia cells from APL patients to differentiate into mature neutrophils both in vitro and in vivo (Huang et al. 1988; Castaigne et al. 1990; Chomienne et al. 1990; Warrell et al. 1991). However, it is currently unknown whether RA and RARs might also be involved in regulating normal hematopoietic differentiation.

Dominant-negative genes encode abnormal proteins that repress the function of their normal counterparts in 
a dominant manner (Herskowitz 1987). A prototype example is the v-erbA oncogene, which represses the transcription-regulating function of normal thyroid hormone receptors (encoded by c-erbA), and this contributes to the transformation of erythroblasts (Zenke et al. 1988; Damm et al. 1989]. A small deletion in the carboxyl terminus of v-erbA appears to be responsible for most of the dominant-negative activity of this oncogene in transient expression assays (Damm et al. 1989; Sap et al. 1989; Zenke et al. 1990). Thus, one way to examine the role of $\mathrm{RAR} \alpha$ in hematopoiesis is to utilize dominant-negative receptor constructs that would suppress normal RAR function in hematopoietic precursors and then determine whether the expression of these constructs would alter the growth and differentiation of these blood cell progenitors.

In this study we have constructed a mutant RAR $\alpha$, which exhibits dominant-negative activity in both mouse NIH-3T3 fibroblasts and in the HL-60 human promyelocytic leukemia cell line. This construct, when introduced into the multipotent interleukin-3 (IL-3)-dependent FDCP mix A4 murine hematopoietic cell line, induces a marked switch from spontaneous neutrophil/ monocyte differentiation to the development of basophils/mast cells. These observations suggest that RARs play important roles in the development of myeloid progenitors.

\section{Results \\ A truncated RAR $\alpha$ construct exhibits dominant- negative activity}

As detailed in Materials and methods we created an RAR $\alpha$ cDNA with a truncation of the sequences coding for the carboxy-terminal 59 amino acids, as well as a portion of the 3'-untranslated region. This truncated cDNA (designated RAR $\alpha 403$ ) encodes a peptide of 403 amino acids containing the amino terminus, the DNAbinding domain, and part of the hormone-binding domain of RAR $\alpha$ (Fig. 1A,B). This truncated receptor was inserted into the retroviral vector LXSN (Fig. 1C) to generate the recombinant vector designated LRAR $\alpha 403 \mathrm{SN}$ (Fig. 1D). To determine whether the truncated RAR $\alpha 403$ construct exhibits dominant-negative activity with respect to the normal RAR $\alpha$, we performed trans-activation assays in mouse NIH-3T3 tk ${ }^{-}$cells. When an expression vector harboring the normal RAR $\alpha$ gene (pEMSV-RAR $\alpha$ ) was cotransfected with a chloramphenicol acetyl transferase $\{\mathrm{CAT}\}$ reporter construct, pTRECAT, containing a synthetic thyroid hormone/RA-responsive element (TRE) (Umesono et al. 1988), there was RA-induced trans-activation of the CAT reporter gene (Fig. 2A, lanes 5,6 ). In contrast, when both pEMSVRAR $\alpha$ and the mutant LRAR $\alpha 403$ SN construct were cotransfected into the same target cells, there was a dose-dependent suppression of this RAR $\alpha$-mediated trans-activation (Fig. 2A, lanes 6-10). An RAR $\alpha$ ) RAR $\alpha 403$ DNA ratio of $1: 6$ suppressed most of the activity of the normal RAR $\alpha$. When this experiment was

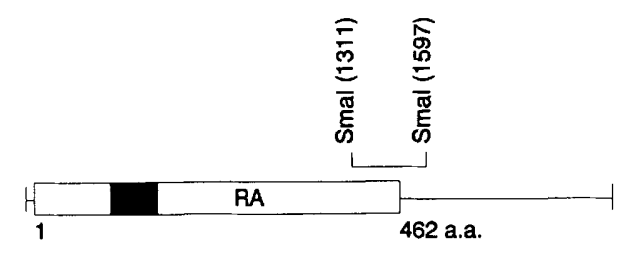

B. RAR $a 403$

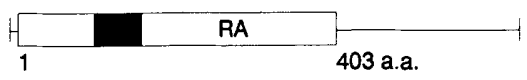

C. LXSN

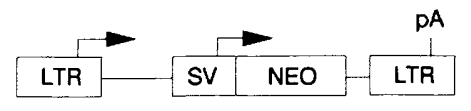

D. LRAR $\propto 403 S N$

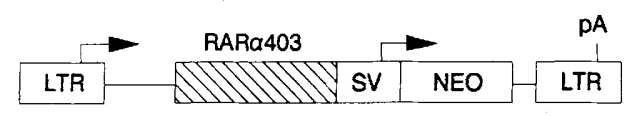

Figure 1. Structures of RAR $\alpha 403$ and the retroviral vector LRAR $\alpha 403 S N$. (A) Schematic representation of human RAR $\alpha$ cDNA (Giguere et al. 1987). The bar represents the open reading frame that encodes the normal human RAR $\alpha$ (462 amino acids). The solid region represents the DNA-binding domain of RAR $\alpha$. (RA) The hormone-binding domain. (B) Structure of the truncated receptor RAR $\alpha 403$ cDNA. Nucleotides 1311-1596 of human RAR $\alpha$ cDNA were deleted by digestion with SmaI, and a stop codon was inserted at amino acid position 404 using an NheI linker. The truncated receptor consists of 403 amino acids and is designated RAR $\alpha 403$. (C) The retroviral vector LXSN (from Miller and Rosman 1989). (LTR) Molony murine leukemia virus long terminal repeat. Arrows indicate the transcription initiation site. (SV) SV40 promotor; (NEO) the neomycin phosphotransferase gene; $(\mathrm{pA})$ the polyadenylation site. $(D)$ The structure of the retroviral vector LRAR $\alpha 403$ SN. RAR $\alpha 403$ was inserted into the EcoRI-BamHI cloning sites of LXSN. This vector may be used both as an expression vector in transient expression assays and for producing retroviral particles.

performed using a different reporter, that is, pRRE-CAT, which harbors the natural RA-response element (RRE) of RAR $\beta$ (de The et al. 1990a), there was prominent suppression of the endogenous RAR activities (Fig. 2B, lanes 3,4 ) and partial suppression of exogenous RAR $\alpha$ activity. (Fig. 2B, lanes 6-9). These results indicate that the RAR $\alpha 03$ construct exhibits dominant-negative activity with respect to the normal RAR $\alpha$ in mouse fibroblasts.

To determine whether this same RAR $\alpha 403$ construct also exhibits dominant-negative activity in hematopoietic cells, we performed transient expression assays in the mouse hematopoietic cell line FDCP mix A4/described below) by electroporation. Although the RAR $\alpha 403$ construct suppressed some endogenous RAR activities in this cell line (data not shown), the extremely low efficiency of gene transfer achievable by electroporation in these target cells (estimated to be $1 / 10,000$ that of NIH-3T3) made them unsuitable for adequately assessing the suppressing potential of RAR $\alpha 403$ by transient expression. To further examine the dominant-negative function of RAR $\alpha 403$ in hematopoietic cells, we utilized retrovirusmediated gene transduction to introduce this mutant re- 
Tsai et al.

Figure 2. The truncated RAR $\alpha 403$ exhibits dominant-negative function in transient expression assays. (A) The trans-activation activities of RAR $\alpha$ and RAR $\alpha 403$ were studied in NIH-3T3 tk $^{-}$cells in the absence and presence of $1 \mu \mathrm{M}$ RA. An expression plasmid pTRE-CAT was used as the reporter. RAR $\alpha$ represents the expression plasmid pEMSV-RAR $\alpha$; RAR $\alpha 403$ refers to pLRAR $\alpha 403 S N$ (Fig. ID). The volume of lysate used in CAT assay was normalized for transfection efficiency determined by expression of the cotransfected growth hormone reporter pCMVGH. The DNA ratio of pEMSV-RAR $\alpha$ to pLRAR $\alpha 403 S N$ varied from $1: 1$ to $1: 6$. pLXSN was used to equalize the total amount $(23.5 \mu \mathrm{g} / 100-\mathrm{mm}$ dish) of DNA and LTRs transfected. $(+\mid 2.5 \mu \mathrm{g}$ of plasmid DNA. Higher amounts $(5 \mu \mathrm{g})$ of transfected pLRAR $\alpha 403 S N$ result in suppression of $>60 \%$ of endogenous RAR activity (not shown). (B) Similar to $A$ except a different reporter (pRRE-CAT) was used in place of pTRE-CAT. $1+\mid 1 \mu \mathrm{g}$ of plasmid DNA. The total amount of DNA was $16 \mu \mathrm{g} / 100-\mathrm{mm}$ dish.
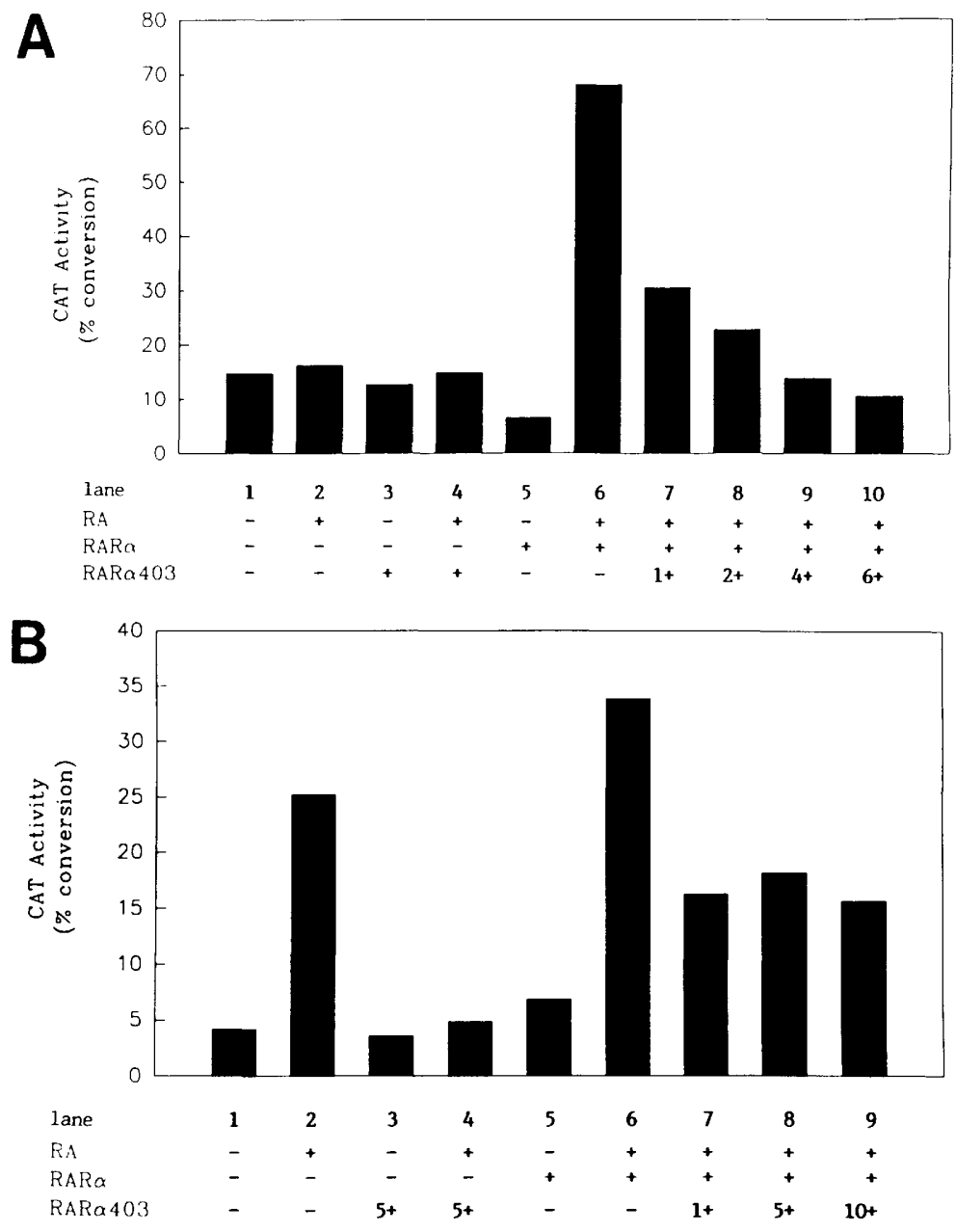

ceptor into the HL-60 human promyelocytic leukemia cell line (Collins et al. 1977). RA induces neutrophilic differentiation of HL-60 cells (Breitman et al. 1980), and this response is mediated directly through RAR $\alpha$ /Collins et al. 1990). As detailed in Materials and methods, we infected HL-60 cells with the amphotropic LRAR $\alpha 403$ SN retroviral vector (Fig. 1D) and utilized Northern blot analysis to identify retroviral vector-infected HL- 60 clones that expressed the mutant RAR $\alpha 403$ mRNA. As a control we also infected HL-60 with the LXSN retroviral vector, which confers G418 resistance but lacks a cDNA insert (Fig. 1C). We then compared the differentiative response of these different retroviral vector-infected HL-60 clones to RA. The control (LXSN)infected HL-60 clones (D.1 and D.2) exhibited a similar response to RA as detailed previously for the parental HL-60 cells (Breitman et al. 1980), with $80-90 \%$ of the cultured cells undergoing morphologic differentiation to mature neutrophils after a 5-day exposure to $10^{-6} \mathrm{M}$ RA (Fig. 3). In contrast, the LRAR $\alpha 403 \mathrm{SN}$-infected HL-60 clones (D.2 and D.5) exhibited marked blunting of this differentiative response to RA with no more than 20$25 \%$ of the cells differentiating to neutrophils after exposure to concentrations of RA up to $10^{-5} \mathrm{M}$ (Fig. 3).

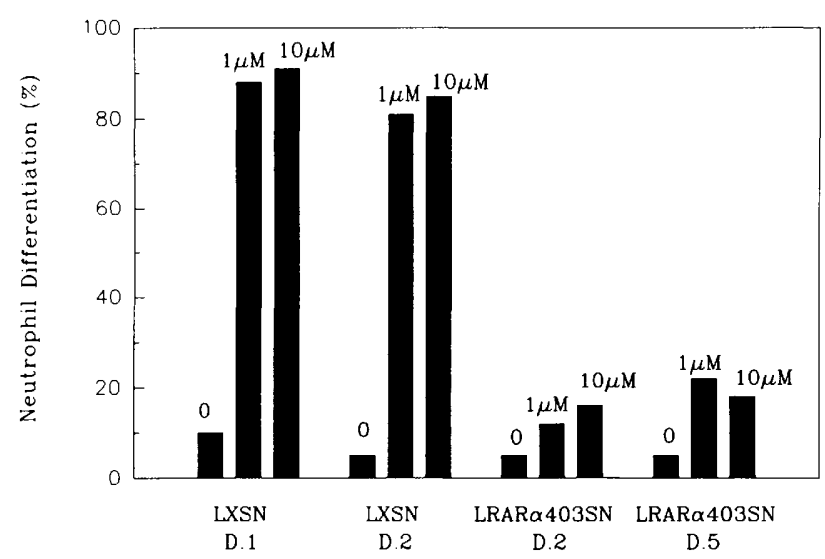

Figure 3. Expression of RAR $\alpha 403$ in HL- 60 cells blunts RAinduced neutrophilic differentiation. HL-60/LXSN D.1 and D.2 are two randomly selected HL-60 clones infected with the control vector LXSN. HL-60/LRAR $\alpha 403$ SN D. 2 and D.5 are two HL- 60 clones infected with LRAR $\alpha 403$ SN that express high levels of the full-length $4.7-\mathrm{kb}$ retroviral vector mRNA containing RAR $\alpha 403$ sequence. Cells were induced with the indicated concentrations of RA for 5 days. Differential counts were then performed on Wright-Giemsa-stained cytospin preparations and represent the means of triplicate experiments. 
These results indicate that the truncated RAR $\alpha 403$ construct also exhibits dominant-negative activity in the HL-60 hematopoietic cell line, and its expression is not lethal in these particular neutrophil progenitors.

\section{Characteristics of FDCP $\operatorname{mix} A 4$ cells}

To examine the impact of the dominant-negative RAR $\alpha 403$ on the commitment and differentiation of multipotent hematopoietic progenitors, we utilized the FDCP mix A4 cell line. This IL-3-dependent cell line was established from a murine long-term bone marrow culture and behaves like normal hematopoietic stem cells in many respects: it is nonleukemogenic, responds to several hematopoietic growth factors in a physiologically relevant manner, and spontaneously generates progenitors committed to different hematopoietic lineages (Spooncer et al. 1986; Just et al. 1991). When cultured in a medium containing horse serum and WEHI $3 \mathrm{~B}$ cell line-conditioned medium (as a source of IL-3), the line maintained in our laboratory consists mainly of undifferentiated blasts (see Fig. 5A, below) but spontaneously differentiates into neutrophils and monocytes/macrophages $(\sim 10-30 \%$ combined) and, to a much lesser extent, into mast cells/basophils (1-2\%). Northern blot analysis indicates that these cells express endogenous 3.6- and 2.6-kb RAR $\alpha$ mRNA transcripts (Fig. 4A, lane 1). Thus, this multipotent hematopoietic cell line appears to be well suited for investigating the impact of the dominant-negative $\operatorname{RAR} \alpha 403$ on hematopoietic differentiation.

\section{Expression of RAR 4403 in FDCP mix A4 cells triggers the development of terminally differentiating basophils/mast cells}

We infected the FDCP mix A4 cells with the amphotropic dominant-negative LRAR $\alpha 403 S N$ retroviral vector, as well as the control vectors (LXSN and LRAR $\alpha S N$; the latter harbors the cDNA of normal human RAR $\alpha$ ) and selected the infected cells in a medium containing G418 and IL-3. Examination of Wright-Giemsa-stained cytospin preparations of FDCP mix A4 cells infected with the control retroviral vectors (LXSN and LRAR $\alpha$ SN) revealed the predominant neutrophilic/ monocytic differentiation characteristic of the uninfected parental FDCP mix A4 cells (Fig. 5A,B,D). In contrast, a very large number of differentiated cells with numerous, intensely basophilic granules appeared in the culture infected with the LRAR $\alpha 403 \mathrm{SN}$ retroviral vector within 10 days after the infection (Fig. 5C,E). These latter cells expressed high levels of the $4.7-\mathrm{kb}$ retroviral mRNA harboring the dominant-negative RAR $\alpha 403$ insert (Fig. 4A, lane 3). The granules of these cells stained metachromatically with toluidine blue (Fig. 5F) and are negative for nonspecific esterase (a monocyte marker) and alkaline phosphatase (a neutrophil marker). These morphological and cytochemical characteristics suggest that these basophilic granular cells are basophils/mast cells.

To further confirm the basophil/mast cell lineage of

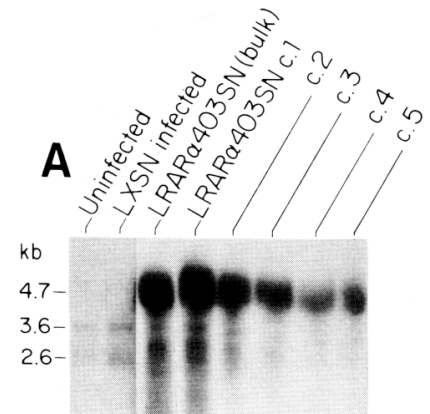

RAR $\alpha$

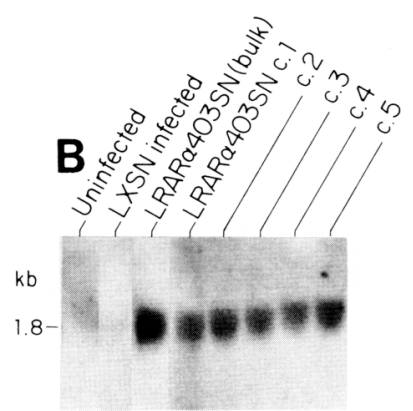

GATA-1
Figure 4. High-level expression of LRAR $\alpha 403 \mathrm{SN}$ and GATA-1 by infected FDCP mix A4 cells. RNAs were prepared from uninfected, control (LXSN)-infected, and LRAR $\alpha 403 \mathrm{SN}$-infected FDCP mix A4 bulk cultures and from five clonal lines (labeled LRAR $\alpha 403 S N$ c. $1-$ c.5) and subjected to Northern blot hybridization. Ten micrograms of total RNA was applied to each lane and hybridized to the indicated probes. $(A)$ Expression of LRAR $\alpha 403 S N$. The full-length message of LRAR $\alpha 403 S N$ is $4.7-$ $\mathrm{kb}$. The RAR $\alpha$ probe also detects the $3.6-$ and $2.6-\mathrm{kb}$ endogenous mouse RAR $\alpha$ mRNA. The ratio of RAR $\alpha 403$ to endogenous RAR $\alpha$ message in cells infected with LRAR $\alpha 403 \mathrm{SN}$ is $>10: 1$. $(B)$ Expression of GATA-1. The 1.8-kb GATA-1 mRNA is indicated.

the basophilic granular cells in the LRAR $\alpha 403 S N$-infected FDCP mix A4 cells, we utilized flow cytometry to examine the expression of cell-surface immunoglobulin E receptor (IgE $\mathrm{R}$ ), another basophil/mast cell-specific marker (Metzger et al. 1986; Thompson et al. 1990). A high percentage $(38.4 \%)$ of cells expressing surface IgE $R$ was noted in LRAR $\alpha 403$ SN-infected cells, whereas only $0.4 \%$ of LXSN-infected cells were positive for IgE R ( Table 1). We also phenotyped LRAR $\alpha 403 S N$ as well as the control (LXSN and LRAR $\alpha S N$ )-infected cultures utilizing monoclonal antibodies specific for mouse neutrophils (antibody 7/4; Hirsch and Gordon 1983) and macrophages (MAC-1 antibody). Consistent with our morphological observations, the LXSN- or LRAR $\alpha S N$ infected FDCP mix A4 cells contained 10-30\% 7/4positive cells, whereas the LRAR $\alpha 403 \mathrm{SN}$-infected cultures exhibited significantly lower percentages $(0-3.5 \%)$ of neutrophil antigen-positive cells (Table 1$)$.

Histamine is a lineage-specific marker for basophils/ mast cells (Riley and West 1953; Denburg 1992). Therefore, we measured both the histamine content within these infected cells and the concentration of histamine in the culture supernatant (Table 1). We found that the histamine content of the LRAR $\alpha 403 \mathrm{SN}$-infected cells $2.17 \mathrm{pg} / \mathrm{cell}$, assuming every cell contained equal amounts of histamine to allow comparison) was $\sim 10$ fold greater than the histamine content of the control LXSN-infected cells $(0.25 \mathrm{pg} /$ cell $)$ and was similar to the histamine content of normal basophils/mast cells. Moreover, the histamine concentration in the supernatant of the LRAR $\alpha 403 \mathrm{SN}$-infected cultures $\left(3 \times 10^{-4} \mathrm{M}\right)$ was $\sim 130$-fold increased over the histamine concentration in the control (LXSN)-infected cells $\left(2.3 \times 10^{-6} \mathrm{M}\right)$ (Table 1). 

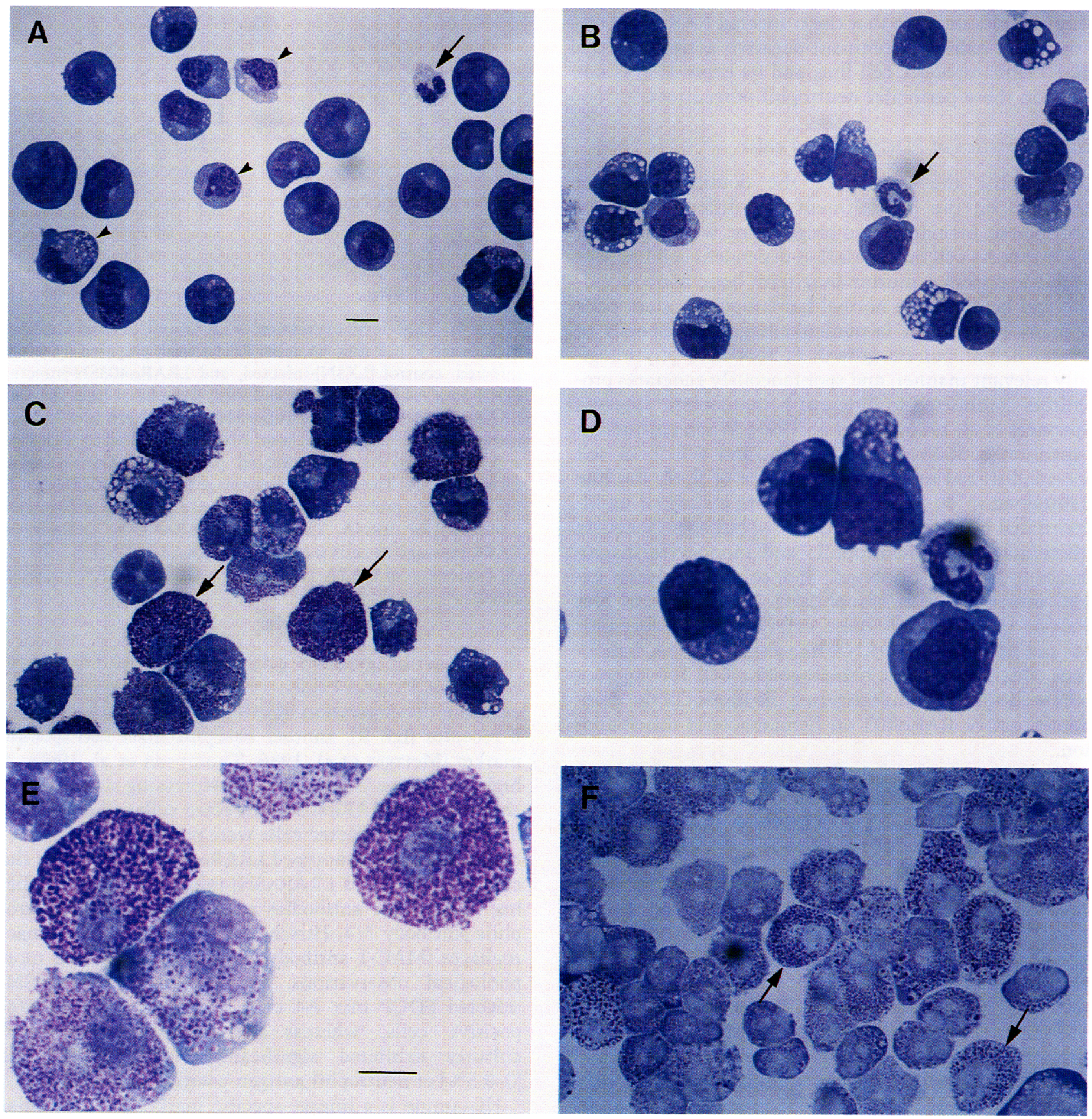

Figure 5. Morphology of uninfected and infected FDCP mix A4 cells. (A) Uninfected FDCP mix A4 cells. Most cells are undifferentiated blasts. The arrow points to a mature neutrophil. Arrowheads indicate differentiating cells. (B) FDCP mix A4 infected with control vector LXSN. The arrow points to a neutrophil. (C) FDCP mix A4 infected with LRAR $\alpha 403 S N$. Most cells (arrows) are differentiated and contain numerous basophilic granules and oval nuclei. $(D)$ A higher magnification of $B$. $(E)$ A higher magnification of $C$. $(F)$ Toluidine blue stain of FDCP mix A4 cells infected with LRAR $\alpha 403 S N$. The granules in many cells (arrows) stain metachromatically with toluidine blue, indicating that these cells are of the basophil/mast cell lineage. $(A-E)$ Wright-Giemsa stain. Bars, 10 $\mu \mathrm{m}$. All except $D$ and $E$ have the same magnification.

We also quantitated the production of basophils/mast cells by FDCP mix A4 cells following retroviral infection and G418 selection. As shown in Figure 6, the production of basophils/mast cells in LRAR $\alpha 403 \mathrm{SN}$-infected cultures was 20- to 70-fold higher than in LXSN-infected cultures in the first 2 weeks after the infection. These observations indicate that retrovirus-mediated gene transfer and expression of the dominant-negative RAR $\alpha 403$ construct in FDCP mix A4 cells resulted in a switch from spontaneous neutrophil/monocyte differen- 
Table 1. Cell-surface antigen expression and histamine production by LXSN- and LRAR- $\alpha 403 S N$-infected FDCP mix A4 cells

\begin{tabular}{|c|c|c|c|c|c|}
\hline \multirow[b]{2}{*}{ Cell line } & \multicolumn{3}{|c|}{ Expression $^{a}$} & \multicolumn{2}{|c|}{ Histamine $^{b}$} \\
\hline & $\begin{array}{l}7 / 4 \mid+1 \\
|\%|\end{array}$ & $\begin{array}{l}\text { MAC- } 1|+| \\
(\%)\end{array}$ & $\begin{array}{l}\operatorname{IgE} R(+) \\
|\%|\end{array}$ & $\begin{array}{l}\text { intracellular } \\
\text { (pg/cell) }\end{array}$ & $\begin{array}{l}\text { in supernatant } \\
\text { (M) }\end{array}$ \\
\hline \multicolumn{6}{|l|}{ Experiment 1} \\
\hline LXSN infected & 28.6 & 8.3 & ND & ND & ND \\
\hline LRAR $\alpha 403 S N$ infected & 1.4 & 1.0 & $\mathrm{ND}$ & ND & ND \\
\hline \multicolumn{6}{|l|}{ Experiment 2} \\
\hline uninfected & 11.1 & 2.0 & ND & 0.14 & $1.6 \times 10^{-6}$ \\
\hline LXSN infected & 14.5 & 2.8 & 0.4 & 0.25 & $2.3 \times 10^{-6}$ \\
\hline LRAR $\alpha$ SN infected & 11.4 & 1.0 & $\mathrm{ND}^{\mathrm{c}}$ & ND & ND \\
\hline LRAR $\alpha 403 S N$ infected & 3.6 & 1.0 & 38.4 & 2.17 & $3.0 \times 10^{-4}$ \\
\hline
\end{tabular}

${ }^{a}$ Cell-surface antigen expression was analyzed using monoclonal antibodies specific for mouse neutrophils (7/4), monocytes/macrophages (MAC-1), or IgE receptor; as detailed in Materials and methods.

${ }^{b}$ Histamine content was determined by radioimmunoassay. For quantification of intracellular histamine, cells were lysed in distilled water. Negative controls included NIH-3T3 fibroblast, which showed no measurable intracellular histamine, and complete culture medium, which contained $<10^{-9} \mathrm{M}$ histamine.

'Examination of Wright-stained cytospin preparations revealed very few basophils/mast cells. The LRAR $\alpha$ SN-infected culture was indistinguishable from uninfected or LXSN-infected FDCP mix A4 cells by morphology.

tiation to the development of basophils/mast cells. We have observed this same phenotype (i.e., markedly increased basophil/mast cell and decreased neutrophil/ monocyte development) in the LRAR $\alpha 403 \mathrm{SN}$-infected

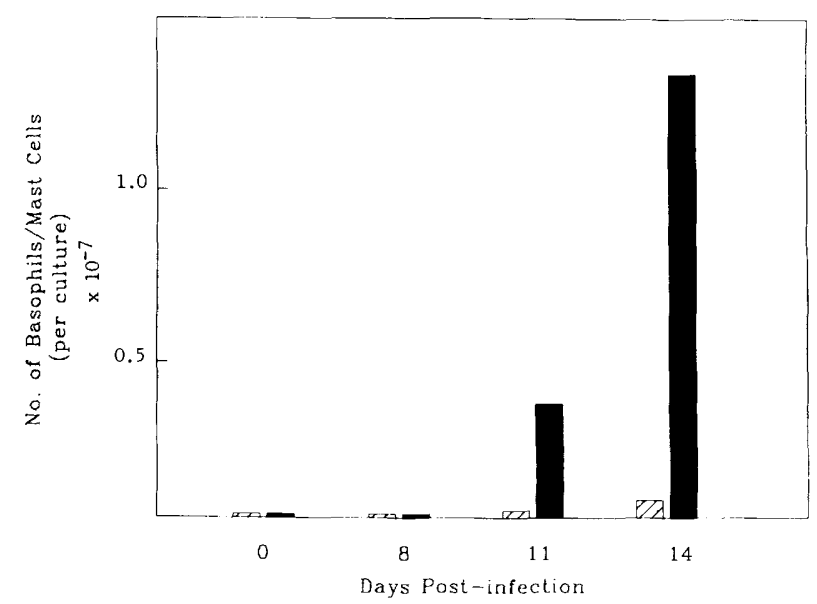

Figure 6. Net production of basophils/mast cells in infected FDCP mix A4 cells. FDCP mix A4 cells $\left(1.4 \times 10^{6}\right.$ cells $)$ were infected with LXSN (hatched bars) or LRAR $\alpha 403 S N$ (solid bars) vectors using the supernatant infection method and selected with G418 from days 2-8. Similar percentages $(10-15 \%)$ of cells infected with either retroviral vector were G418 resistant. These G418-resistant cells were subsequently maintained in culture medium supplemented with WEHI-3B-conditioned medium (as a source of IL-3) and subcultured every 3 days. Production of basophils/mast cells was calculated from the total number of cells and the differential counts on Wright-stained cytospin preparations on each feeding. The total numbers of cells (corrected for subculturing ratios) for LXSN-infected cultures were $1.3 \times 10^{6}$ (day 8 ), $10.1 \times 10^{6}$ (day 11 ), and $93.8 \times 10^{6}$ (day 14). Corresponding numbers for LRAR $\alpha 403 S N$-infected cultures were $1.3 \times 10^{6}$ (day 8 ), $5.5 \times 10^{6}$ (day 11 ), and $16.8 \times 10^{6}$ (day 14). All numbers represent mean of duplicates.
FDCP mix A4 cells during continuous passaging for $>9$ months.

\section{FDCP mix A4 cells infected with LRAR $\alpha 403 S N$ exhibit diminished self-renewal}

The LRAR $\alpha 403 S N$-infected FDCP mix A4 cells exhibited a marked decrease in growth rate (population doubling time of $\sim 120 \mathrm{hr}$ ) compared with the control (LXSN)-infected cultures (population doubling time of $\sim 30 \mathrm{hr}$ ) (Fig. 7). The prolongation of population doubling time of LRAR $\alpha 403 S N$-infected FDCP mix A4 cells occurred around passages $2-5$ and coincided with the appearance of a large number of basophils/mast cells and a decreased number of undifferentiated blasts. These ob-

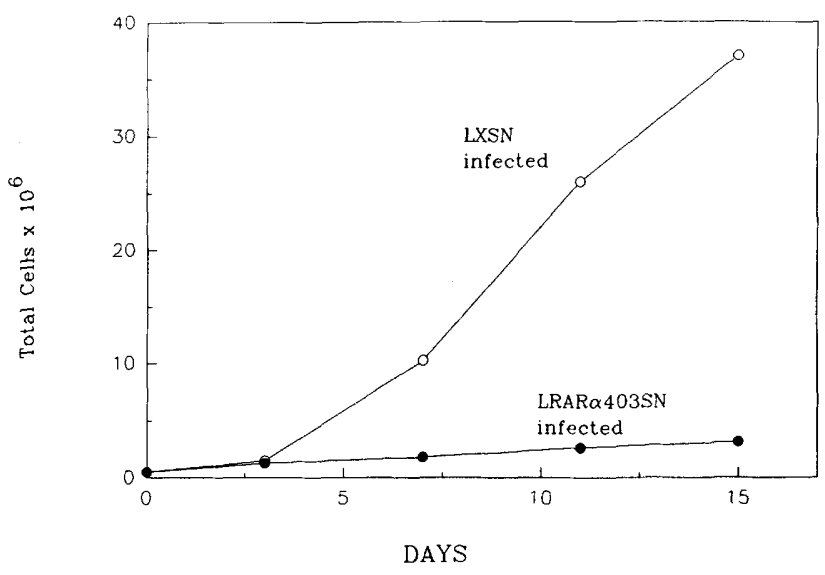

Figure 7. Growth curves of FDCP mix A4 cells infected with LRAR $\alpha 403 S N$. Cultures were initiated with $2 \times 10^{5}$ low-passage (p.7) cells of bulk cultures of FDCP mix A4 cells infected with the indicated retroviral vectors and subcultured every $3-4$ days. Each data point represents the mean of duplicates. 
Tsai et al.

servations suggest that the decreased growth rate of LRAR $\alpha 403$ SN-infected FDCP mix A4 cells might be due in part to diminished self-renewal of undifferentiated blasts. Therefore, we measured the frequency of cells capable of forming macroscopic colonies in agar cultures in the presence of IL-3. (The macroscopic colonies are defined as colonies with a diameter $>0.5 \mathrm{~mm}$ after a 14-day incubation and are formed by cells with greater self-renewal capacity.) The frequency of macroscopic colony-forming cells of FDCP mix A4 cells infected with LRAR $\alpha 403 S N$ was $0.028 \%$, which was 18 -fold lower than that of LXSN-infected cells $(0.5 \%)$. Furthermore, even the macroscopic colony forming cells in the LRAR $\alpha 403 S N$-infected cultures demonstrated a relatively lower self-renewal capacity compared with those in the LXSN-infected cultures because $80 \%$ of the individual macroscopic colonies of the latter, when transferred to liquid suspension cultures, were capable of long-term continuous proliferation in IL-3-containing media while only $20 \%$ of macroscopic colonies of LRAR $\alpha 403 S N$-infected FDCP mix A4 cells demonstrated this proliferative capacity.

Examination of cytospin preparations of individual macroscopic colonies showed that all such colonies of LRAR $\alpha 403 \mathrm{SN}$-infected FDCP mix A4 cells contained high percentages (mean $47.9 \%$ ) of basophils/mast cells and lower percentages of neutrophils, monocytoid cells, and undifferentiated blasts when compared with LXSNinfected cells (Table 2). Thus, the phenotypic change we observed in the bulk culture of LRAR $\alpha 403 \mathrm{SN}$-infected FDCP mix A4 cells was recapitulated by all clonogenic cells.

\section{All clonal lines of LRAR $403 S N$-infected FDCP mix A4 cells exhibit predominant basophil/mast cell differentiation}

The above analysis was performed on "bulk" cultures of G418-resistant retroviral vector-infected FDCP mix A4 cells. We also utilized soft agar cloning and limiting dilution to establish five continuously passaged clonal lines of the LRAR $\alpha 403 \mathrm{SN}$-infected cells. All of these clones (c.1-c.5) expressed the appropriate $4.7-\mathrm{kb}$ retroviral mRNA (Fig. 4A). We noted that the phenotype of these subclones was virtually identical to the bulk-infected cells. That is, all five subclones exhibited slower IL-3-dependent growth, and Wright-Giemsa-stained cytospin preparations revealed high percentages of basophils/mast cells and lower percentages of neutrophils and undifferentiated blasts in these subclones when compared with clones of LXSN-infected FDCP mix A4 cells. This phenotype is further substantiated by flow cytometry using monoclonal antibodies 7/4, MAC-1, and IgE (Table 3).

Table 2. Differential counts of macroscopic colonies in agar culture of LXSN-and LRAR $403 S N$-infected FDCP mix A4 cells

\begin{tabular}{|c|c|c|c|c|}
\hline Colony number & Basophil/mast cell $(\%)$ & Neutrophil (\%) & Monocytoid $(\%)$ & Undifferentiated (\%) \\
\hline \multicolumn{5}{|c|}{ LXSN-infected cells } \\
\hline 1 & 1 & 13 & 52 & 34 \\
\hline 2 & 2 & 2 & 18 & 78 \\
\hline 3 & 1 & 7 & 23 & 69 \\
\hline 4 & 0 & 13 & 24 & 63 \\
\hline 5 & 1 & 5 & 31 & 63 \\
\hline 6 & 0 & 6 & 5 & 89 \\
\hline 7 & 3 & 16 & 31 & 50 \\
\hline 8 & 3 & 7 & 43 & 47 \\
\hline 9 & 0 & 2 & 2 & 96 \\
\hline 10 & 0 & 7 & 23 & 70 \\
\hline Mean & 1.1 & 7.8 & 25.2 & 65.9 \\
\hline \multicolumn{5}{|c|}{ LRAR $\alpha 403 S N$-infected cells } \\
\hline 1 & 59 & 0 & 8 & 33 \\
\hline 2 & 51 & 0 & 8 & 41 \\
\hline 3 & 26 & 0 & 7 & 67 \\
\hline 4 & 52 & 3 & 17 & 28 \\
\hline 5 & 50 & 3 & 15 & 32 \\
\hline 6 & 59 & 2 & 17 & 22 \\
\hline 7 & 25 & 3 & 30 & 42 \\
\hline 8 & 66 & 0 & 11 & 23 \\
\hline 9 & 60 & 2 & 14 & 24 \\
\hline 10 & 31 & 0 & 37 & 32 \\
\hline Mean & 47.9 & 1.3 & 16.4 & 34.4 \\
\hline
\end{tabular}

Colony assays were performed as described in Materials and methods. Individual macroscopic colonies (>0.5 mm diam.) were identified with a dissecting microscope, and cytospin preparations were made of individual colonies and stained with Wright-Giemsa stain. Differential counts were performed on 100 cells each. 
Table 3. Cell-surface antigen expression by clonal lines of FDCP mix A4 cells infected with LXSN and LRAR $\alpha 403 S N$ retroviral vectors

\begin{tabular}{|c|c|c|c|}
\hline Clone & $\begin{array}{l}\operatorname{IgE} R(+1 \\
|\%|\end{array}$ & $\begin{array}{l}7 / 4 \mid+1 \\
(\%)\end{array}$ & $\begin{array}{l}\text { MAC-1 } 1+) \\
(\%)\end{array}$ \\
\hline \multicolumn{4}{|c|}{ LXSN-infected cells } \\
\hline c. 1 & 0.0 & 17.4 & 7.4 \\
\hline c. 2 & 6.2 & 23.1 & 9.1 \\
\hline c.3 & 3.9 & 21.2 & 29.0 \\
\hline c. 4 & 4.0 & 24.2 & 7.9 \\
\hline c.5 & 3.6 & 17.8 & 8.5 \\
\hline Mean & 3.5 & 20.7 & 12.4 \\
\hline \multicolumn{4}{|c|}{ LRAR $\alpha 403 S N$-infected cells } \\
\hline c. 1 & 47.4 & 1.9 & 0.9 \\
\hline c. 2 & 54.4 & 1.3 & 0.9 \\
\hline c. 3 & 66.4 & 0 & 0 \\
\hline c. 4 & 56.3 & 0 & 0 \\
\hline c.5 & 74.9 & 0 & 0 \\
\hline Mean & 59.9 & 0.6 & 0.4 \\
\hline
\end{tabular}

Clonal lines were established by limiting dilution subcloning in 96-well plates or in soft agar. Flow cytometry was performed as described in Materials and methods.

\section{Enhanced GATA-1 expression in LRARa403SN-infected} FDCP mix A4 cells

GATA-1 is a zinc finger-containing transcription factor that is preferentially expressed in hematopoietic cells of the erythroid, megakaryocyte, and mast cell lineages but not in neutrophilic or monocytic lineages (Tsai et al. 1989; Martin et al. 1990). Although GATA-1 was initially identified as a transcriptional regulator of globin gene expression, recent studies show that GATA-1 also binds to the promotor region of the gene of mast cellspecific carboxypeptidase $\mathrm{A}$ and activates its expression (Zon et al. 1991). We utilized Northern blot hybridization to compare GATA-l mRNA levels in the LRAR $\alpha 403 S N$-infected FDCP mix A4 cells versus the control (LXSN)-infected cells. Relatively low levels of GATA-1 mRNA were detected in the LXSN-infected FDCP mix A4 cells. In contrast, a marked increase in steady-state GATA-1 mRNA was noted in the LRAR $\alpha 403 S N$-infected bulk cultures as well as the five individual infected subclones (Fig. 4B). This enhanced GATA-1 mRNA expression noted in the LRAR $\alpha 403 S N$ infected FDCP mix A4 cells further corroborates the other basophil/mast cell characteristics displayed by many of these cells.

\section{Discussion}

In this study we have observed that introducing a mutant RAR $\alpha$ exhibiting dominant-negative activity into the IL-3-dependent, multipotent FDCP mix A4 murine hematopoietic cell line results in a dramatic change in the lineage development of these cells. Although the FDCP mix A4 cell line is by no means the equivalent of normal hematopoietic stem cells, it preserves many properties of multipotent hematopoietic progenitors and thus serves as a useful model for analyzing molecular events involved in myeloid differentiation. This cell line ordinarily commits spontaneously to neutrophilic and monocytic differentiation at moderate frequencies, but upon introduction of the dominant-negative RAR $\alpha 403$ construct there is a rapid switch to the development of terminally differentiated cells with basophilic cytoplasmic granules (Fig. 5C,E). These differentiated cells exhibit many characteristics of basophils/mast cells, including metachromatic staining with toluidine blue (Fig. $5 F$ ), histamine production (Table 1), expression of cellsurface IgE receptor (Table 1), and enhanced GATA-1 mRNA levels (Fig. 4B).

The development of basophils/mast cells in the LRAR $\alpha 403 S N$-infected cultures is attributable to the expression of the dominant-negative RAR $\alpha 403$ construct. None of the cultures infected with the control vectors (LXSN and LRAR $\alpha$ SN) preferentially differentiates into basophils/mast cells. In contrast, all of the LRAR $\alpha 403 S N$-infected subclones that we have analyzed exhibit predominantly basophil/mast cell phenotype (Tables 2 and 3). Moreover, the characteristic basophil/ mast cell morphological and histochemical changes occur rapidly (within 10 days) after infection with this dominant-negative RAR $\alpha 403$ retroviral construct. These observations exclude rare events such as retroviral vector-induced mutation as the cause of the prominent phenotypic changes in the cultures. In addition, we have observed that continuous passaging of control (LXSN)infected FDCP mix A4 cells for 9 months does not result in the conversion to basophil/mast cell development, further excluding random mutation as the cause of the observed phenotypic changes.

Our observation that many clones of LRAR $\alpha 403 \mathrm{SN}$ infected FDCP mix A4 cells continue to produce a small number of neutrophils and monocytes in addition to the large number of basophils/mast cells (Tables 2 and 3 ) indicates that the individual clonogenic cells are at least tripotent [i.e., capable of differentiating into (1) basophils/mast cells, (2) neutrophils, and (3) monocytes]. Therefore, the observed phenotypic change does not result from immortalization of any rare committed, unipotent basophil/mast cell progenitors. (In fact, the basophils/mast cells in LRAR $\alpha 403 S N$-infected cultures have a limited life span of 6-12 days and degenerate thereafter.) Rather, this phenotype is the result of a shift by the multipotent FDCP mix A4 cells from the spontaneous production of primarily neutrophils and monocytes to the continuous, preferential production of basophil/ mast cells. It should be emphasized that the net production (absolute number) of basophils/mast cells produced by LRAR $\alpha 403 \mathrm{SN}$-infected FDCP mix A4 cells is increased by 20- to 70 -fold within the first 2 weeks of infection. (Fig. 6). This finding makes it unlikely that the altered FDCP mix A4 phenotype is the result of selective elimination of neutrophils and monocytes in the culture resulting in the progressive accumulation of basophils/ mast cells. In this latter scenario, the percentage of ba- 
sophils/mast cells would increase in the infected cultures, but the absolute number would not.

Concomitant with the switch from spontaneous neutrophil/monocyte differentiation to the development of basophils/mast cells, the LRAR $\alpha 403 \mathrm{SN}$-infected cells exhibit lower percentages of morphologically undifferentiated blasts (Table 2), display an 18 -fold reduction in the frequency of macroscopic colony-forming cells, and show a markedly reduced growth rate (Fig. 7). These three parameters suggest that the self-renewal of LRAR $\alpha 403 S N$-infected cells has decreased, either owing to the prolongation of the cell cycle of undifferentiated blast cells, to the increased recruitment of these cells into the terminal differentiation pathway, or both. The effects of the dominant-negative RAR $\alpha 403$ on the development of different myeloid lineages and the self-renewal of FDCP mix A4 cells are schematically summarized in Figure 8.

Our observation that introducing a dominant-negative RAR $\alpha$ construct into the FDCP mix A4 cells results in a dramatic change from spontaneous neutrophil and monocyte differentiation to basophil/mast cell develop-

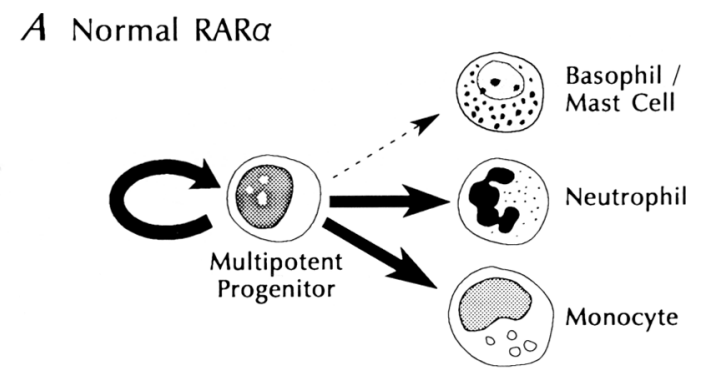

\section{$B$ RAR $\alpha$ Suppressed}

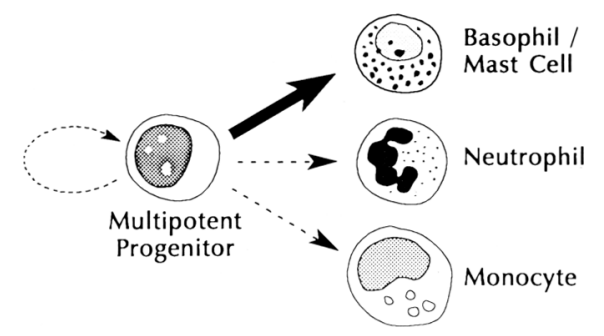

Figure 8. Schematic summary of the effects of the dominantnegative RAR $\alpha 403$ on the lineage development of FDCP mix A4 cells. $(A)$ When RAR $\alpha$ is presumably functioning normally, the IL-3-dependent FDCP mix A4 cells exhibit prominent self-renewal and a predominance of spontaneous differentiation along the neutrophil and monocyte lineages (solid arrows). Spontaneous differentiation to basophil/mast cell lineage is suppressed (broken arrows). (B) In FDCP mix A4 cells infected with the dominant-negative LRAR $\alpha 403 S N$ retroviral vector, the normal RAR $\alpha$ function is presumably suppressed. These cells now exhibit prominent spontaneous differentiation to basophils/mast cells, and differentiation to neutrophils and monocytes is suppressed. The infected cells remain IL-3 dependent, but self renewal is markedly diminished. ment indicates that the normal RAR $\alpha$ plays important roles in regulating the development of myeloid progenitors. It appears that normal RAR $\alpha$ promotes the development of neutrophils and monocytes but represses the development of basophils/mast cells. One possible model is that the normal RAR $\alpha$ blocks the development of basophils/mast cells by uninfected FDCP mix A4 cells. Removal of this blockade by the dominant-negative RAR $\alpha 403$ allows the development along the basophil/mast cell lineage under the strong influence of IL-3 used to maintain the culture. (IL-3 is a potent inducer of basophil/mast cell differentiation by normal hematopoietic stem cells.) In this model, the normal RAR $\alpha$ does not necessarily play the role of a "master switch" that commits cells to different specific hematopoietic lineages. More likely, this transcription factor plays some important role or roles in the complex cascade of molecular events leading to or subsequent to the lineage commitment process. It is important to note that this apparent hematopoietic regulatory activity of RAR $\alpha$ occurs in the relatively low concentrations of RA that are endogenous to serum $\mid<10^{-8} \mathrm{M}_{\text {; }}$ DeRuyter et al. 1979; Cullum and Zile 1986). (There is $20 \%$ horse serum in our complete culture media.) This suggests that RAR $\alpha$ exerts its hematopoietic regulatory activity in FDCP mix A4 cells either in the absence of or in relatively low concentrations of ligand. In contrast, significantly higher concentrations of $\mathrm{RA}\left(10^{-7}\right.$ to $\left.10^{-5} \mathrm{M}\right)$ are required to induce the differentiation of promyelocytic leukemia cells (Breitman et al. 1980; Chomienne et al. 1990) or to activate genes at the $5^{\prime}$ end of the Hox-2 cluster in human embryonal carcinoma cells (Simeone et al. 1990).

Although it is clear from cotransfection studies in NIH-3T3 fibroblasts (Fig. 2) that the RAR $\alpha 403$ construct exhibits dominant-negative activity against the normal RAR $\alpha$, the full spectrum of its biological activity is yet to be defined. The prototype dominant-negative nuclear receptor is the v-erbA oncogene, which exhibits deletions in the carboxy-terminal ligand-binding domain compared with its homolog c-erbA, the thyroid hormone receptor. These carboxy-terminal deletions abolish $\mathrm{T}_{3}$ binding to the v-erbA protein, and as a result v-erbA protein may interfere with normal thyroid hormone function by forming heterodimers with c-erbA that cannot be activated by $\mathrm{T}_{3}$ (Damm et al. 1989; Desbois et al. 1991). Our RAR $\alpha 403$ construct involves a 59-amino-acid truncation in the carboxy-terminal RA binding domain, which most likely also interferes with ligand (RA) binding. Thus, RAR $\alpha 403$ may interfere with normal RAR $\alpha$ function by forming inactive heterodimers with RAR $\alpha$. Alternatively, the mutated RAR $\alpha$ may compete for interactions with other transcription factors that may be essential for RAR $\alpha$ activity. For example, members of the RXR family of RA receptors can dimerize with RARs, and these heterodimers display greater affinity for specific DNA target sequences than do RAR homodimers (Kliewer et al. 1992; Leid et al. 1992; Yu et al. 1992; Zhang et al. 1992). The RAR $\alpha 403$ gene product potentially may form inactive heterodimers with RXRs, and this sequestration of RXRs may prevent the latter 
from potentiating the activity of other RA receptors. Of relevance is the finding that a truncated construct containing the first 404 amino acids of RAR $\alpha$ (differing from our RAR $\alpha 403$ construct by only a single amino acid) can dimerize with RXRs (Yu et al. 1992). Thus, it is possible that the dominant-negative RAR $\alpha 403$ exerts its biologic effects not only by directly inhibiting the normal RAR $\alpha$ but also by indirectly inhibiting related receptors whose full function depends on dimerization with RXRs.

The data reported here indicate that in the multipotent IL-3-dependent FDCP mix A4 murine hematopoietic cell line, RAR $\alpha$ and/or related molecules positively influence the development of neutrophils and monocytes, as well as the self-renewal pathway, but repress the development of basophils/mast cells. We do not know whether RAR $\alpha$ directly participates in this hematopoietic lineage commitment process or, alternatively, is involved in regulating the differentiation after lineage commitment has occurred. In either case, the alteration in the lineage development of the multipotent FDCP mix A4 hematopoietic cell line following the transduction of the dominant-negative RAR $\alpha$ construct indicates that RAR $\alpha$ and/or closely related molecules play important roles in the development of neutrophils, monocytes, and basophils/mast cells.

\section{Materials and methods}

\section{Plasmid constructions}

The sequence of full-length cDNA of human RAR $\alpha$ has been published (Giguere et al. 1987). The plasmid pGEM3Z-hRAR $\alpha$ D5' harbors human RAR $\alpha$ cDNA sequences from the initiator ATG to the BamHI site at position 2103. This plasmid was digested with SmaI, which cut at position 1311 and 1597 of RAR $\alpha$ cDNA (Fig. 1A). The larger fragment was isolated, ligated with an NheI linker (which inserted a stop codon), and recircularized. The new construct was designated pGEM3Z-RAR $\alpha 403$ (Fig. 1B). An EcoRI site was present in the pGEM3Z polylinker immediately $5^{\prime}$ to the initiator ATG of the RAR $\alpha 403$ insert. The 1.8-kb EcoRI-BamHI fragment of pGEM3Z-RAR $\alpha 403$ was then cloned into the EcoRI-BamHI site of the retroviral vector LXSN (Fig. 1C) (Miller and Rosman 1989), and the recombinant vector was designated pLRAR $\alpha 403 S N$ (Fig. 1D). The plasmid pLRAR $\alpha$ SN was constructed by subcloning a 2.8-kb EcoRI fragment of human RAR $\alpha$ cDNA clone (Giguere et al. 1987) into the EcoRI site of pLXSN as detailed previously (Collins et al. 1990). The expression plasmid pEMSV-RAR $\alpha$ was constructed by cloning the $2.8-\mathrm{kb}$ human RAR $\alpha$ cDNA into the EcoRI site of the expression vector pEMSVscribe (Davis et al. 1987). Plasmids pTRE-CAT and pRRE-CAT consist of a single copy of either a synthetic palindromic TRE (5'TCAGGTCATGACCTGA-3') (Umesono et al. 1988) or the RRE identified in the RAR $\beta$ promoter (5'-GTAGGGTTCACCGAAAGTTCACTC-3') (de The et al. 1990al inserted upstream of the thymidine kinase promoter $(-109$ to +5$)$ and CAT reporter gene and was obtained from Jeannette Bigler (Fred Hutchinson Cancer Research Center). Plasmid pCMV-GH was constructed by inserting a $1.1-\mathrm{kb}$ PstI-XbaI fragment containing the cytomegalovirus immediate early gene promotor from pON249 (Geballe et al. 1986) into the human growth hormone reporter construct $\mathrm{p} \phi \mathrm{GH}$ (Nichols Institute, San Juan Capistrano, CA) and was provided by Ed Agura (Fred Hutchinson Cancer Research Center).

\section{Transient expression assays}

$\mathrm{NIH}-3 \mathrm{~T} 3 \mathrm{tk}^{-}$cells were maintained in Dulbecco's modified Eagle medium (DMEM) supplemented with $10 \%$ fetal calf serum (FCS) and plated $24 \mathrm{hr}$ before transfection. The medium was replaced with fresh DMEM supplemented with $10 \%$ charcoalresin-stripped FCS $4 \mathrm{hr}$ before transfection. Cells were transfected by calcium phosphate precipitatation with $2.5 \mu \mathrm{g}$ of pEMSV-RAR $\alpha$, varied amounts of pLRAR $\alpha 403 S N, 2.5 \mu \mathrm{g}$ of pTRE-CAT, $1 \mu \mathrm{g}$ of pCMV-GH as an internal control for tranfection efficiency, and pLXSN to equalize the total amount $(23.5$ $\mu \mathrm{g} / 100-\mathrm{mm}$ dish) of DNA and long terminal repeats (LTRs) transfected. For transient expression assays using pRRE-CAT as the reporter, the following conditions were employed: $1 \mu \mathrm{g}$ of pEMSV-RAR $\alpha$, varied amounts of pLRAR $\alpha 403 S N, 4 \mu \mathrm{g}$ of pRRE-CAT, $1 \mu \mathrm{g}$ of pCMV-GH, and pLXSN to equalize the total amount (16 $\mu \mathrm{g} / 100-\mathrm{mm}$ dish) of DNA and LTRs transfected. Sixteen hours after transfection, the cells were washed with PBS and refed with DMEM supplemented with $10 \%$ charcoal-resin-stripped FCS and incubated for another $32 \mathrm{hr}$ with or without $10^{-6} \mathrm{M}$ ATRA. Electroporation of FDCP mix A4 cells was performed in 0.4-mm cuvettes using a Bio-Rad gene pulser (Richmond, CA) with the following parameters: $2 \times 10^{7}$ cells, $25 \mu \mathrm{F} / 800 \mathrm{~V}, 75 \mu \mathrm{g}$ each of pCMV-GH, pRRE 4 -CAT (containing four copies of RRE instead of one), pEMSV-RAR $\alpha$ and pLRAR $\alpha 403$ SN. Culture supernatants were collected for determination of growth hormone concentration using a radioimmunoassay kit (Nichols Institute). Preparation of cell lysates and CAT assay were performed according to published methods (Sambrook et al. 1989). The volume of cell lysate used in the CAT assay was normalized for transfection efficiency as determined by the growth hormone reporter (pCMV-GH) internal control. Following thin layer chromatography on silica gel, the nonacetylated and acetylated ${ }^{14} \mathrm{C}$-labeled chloramphenicol was quantitated by a PhosphorImager and ImageQuant software (Molecular Dynamics).

\section{Retroviral producer cell lines and retroviral infection}

Amphotropic viral producer cell lines were established according to published procedures (Miller and Rosman 1989). Briefly, pLRAR $\alpha 403$ SN plasmid was transfected into the ecotropic viral packaging cell line PE501, and the transiently expressed viral particles were rescued to infect the amphotropic viral packaging cell line PA317 (Miller 1990). Infected PA317 cells were selected in G418-containing medium, followed by subcloning. One clone, PA317/LRAR $\alpha 403$ SN c. 10, expressing high levels of retroviral mRNA of the predicted size by Northern blot analysis and producing supernatants with a titer of $4 \times 10^{6}$ to $6 \times 10^{6}$ colony-forming units $(\mathrm{CFU}) / \mathrm{ml}$, as assayed on NIH-3T3 tk $^{-}$ cells was chosen as the producer of retroviral vector particles for this study. A cell line, PA317/LRAR $\alpha$ SN producing a retroviral vector (LRAR $\alpha$ SN) harboring the cDNA of the normal human RAR $\alpha$ was established similarly as described previously (Collins et al. 1990|.

HL-60 and FDCP mix A4 cells were infected with retroviral vectors by either a $24-\mathrm{hr}$ cocultivation with irradiated (1200 rads) viral producers or infection with viral supernatants in the presence of $4 \mu \mathrm{g} / \mathrm{ml}$ of polybrene. Infected cells were then selected in complete culture medium containing $1 \mathrm{mg} / \mathrm{ml}$ (for $\mathrm{HL}-60$ ) or $300 \mu \mathrm{g} / \mathrm{ml}$ (for FDCP mix A4) of G418 for 8-10 days. Clonal lines were generated by limiting dilution in 96 -well plates or cloning in $0.3 \%$ agar.

\section{Cell cultures}

HL-60 cells were maintained in RPMI 1640 supplemented with $5 \%$ FCS. FDCP mix A4 cells were maintained in Iscove's mod- 
ified Dulbecco's medium (IMDM) supplemented with 20\% (vol/vol) horse serum and $10 \%$ (vol/vol) WEHI 3B cell lineconditioned medium (as a source of IL-3) and subcultured every 3 days. Colony assays of A4/LXSN and A4/LRAR $\alpha 403 S N$ were done in IMDM supplemented with $25 \%$ horse serum, $10 \%$ WEHI 3B-conditioned medium, and $0.3 \%$ agar. These agar cultures were incubated at $37^{\circ} \mathrm{C}$ in $5 \% \mathrm{O}_{2}, 5 \% \mathrm{CO}_{2}$ and $90 \% \mathrm{~N}_{2}$ for 14 days.

\section{Northern blots}

Total RNAs were extracted with guanidine hydrochloride and subjected to Northern blotting in formaldehyde gels as described previously (Collins et al. 1987). Molecular probes used in Northern hybridization included the following: hRAR $\alpha$, the 1.3-kb EcoRI-SmaI fragment of the phK1 RAR $\alpha$ cDNA clone (Giguere et al. 1987), and the mouse GATA-1 cDNA probe (Tsai et al. 1989), which was obtained from David Martin (Fred Hutchinson Cancer Research Center). All probes were labeled with ${ }^{32} \mathrm{P}$ by nick translation before hybridization.

\section{Cell phenotyping}

Cytospin preparations of cell suspensions were stained with $1 \%$ toluidine blue for $15 \mathrm{~min}$ and washed with tap water. For quantitation of intracellular histamine, $2 \times 10^{5}$ cells were washed with PBS and resuspended in $1 \mathrm{ml}$ of distilled water and lysed by three cycles of freezing and thawing. Radioimmunoassay of histamine in cell lysates or culture supernatants was performed according to the manufacturer's instructions (Immunotech International).

For flow cytometry, cells were exposed to saturating concentrations of primary rat IgG2a monoclonal antibodies $7 / 4$ /generously provided by S. Gordon, Oxford, UK) or MAC-1 (PharMigen) at $4^{\circ} \mathrm{C}$ for $10 \mathrm{~min}$, washed with $\mathrm{PBS} / 1 \% \mathrm{FCS}$, and stained with an FITC-labeled goat anti-rat $\operatorname{IgG}(\mathrm{H}+\mathrm{L})$ for $10 \mathrm{~min}$ at $4^{\circ} \mathrm{C}$. After final washing with PBS/1\% FCS, fluorescence was measured with a Becton-Dickinson FACScan flow cytometer and analyzed by the Reproman software (Kirkegaard \& Perry Labs, MD). An irrelevant rat IgG2a monoclonal antibody (PharMigen) was used as the isotype control. For IgE R staining, cells were incubated with culture medium containing $15 \mu \mathrm{g} / \mathrm{ml}$ of mouse IgE (PharMigen) at $37^{\circ} \mathrm{C}$ overnight, washed three times with PBS $/ 1 \%$ FCS, stained with FITC-goat anti-mouse IgE (Nordic Immunologicals) at $4^{\circ} \mathrm{C}$ for $10 \mathrm{~min}$, followed by washing with PBS $/ 1 \%$ FCS.

\section{Acknowledgments}

We are most grateful to Drs. Elaine Spooncer and Michael Dexter for making the FDCP mix A4 cell line available to us and to Hal Weintraub for his critical reading of the manuscript. We also thank Dusty Miller for the gift of the retroviral vector LXSN and the retroviral packaging cell lines, and LeMoyne Mueller and Babak Emami for excellent technical assistance. This work was supported by American Cancer Society research grant MV-455 to S.J.C.

The publication costs of this article were defrayed in part by payment of page charges. This article must therefore be hereby marked "advertisement" in accordance with 18 USC section 1734 solely to indicate this fact.

\section{References}

Alcalay, M., D. Zangrilli, P. Pandolfi, L. Longo, A. Mencarelli, A. Giacomucci, M. Rocchi, A. Biondi, A. Rambaldi, F. Lo Coco, D. Diverio, E. Donti, F. Grignani, and P. Pelicci. 1991. Translocation breakpoint of acute promyelocytic leukemia lies within the retinoic acid receptor $\alpha$ locus. Proc. Natl. Acad. Sci. 88: 1977-1981.

Borrow, J., A.D. Goddard, D. Sheer, and E. Solomon. 1990. Molecular analysis of acute promyelocytic leukemia breakpoints cluster region on chromosone 17. Science 249: 15771580.

Breitman, T.R., S.E. Selonick, and S.J. Collins. 1980. Induction of differentiation of the human promyelocytic leukemia cell line (HL-60) by retinoic acid. Proc. Nat1. Acad. Sci. 77: 29362940.

Castaigne, S., C. Chomienne, M.T. Daniel, P. Ballerini, R. Berger, P. Fenaux, and L. Degos. 1990. All-trans retinoic acid as a differentiation therapy for acute promyelocytic leukemia. I. Clinical results. Blood 76: 1704-1710.

Chomienne, C., P. Ballerini, N. Balitrand, M. Daniel, P. Fenaux, S. Castaigne, and L. Degos. 1990. All-trans retinoic acid in acute promyelocytic leukemias. II. In vitro studies: Structure-function relationship. Blood 76: 1710-1717.

Collins, S.J., R.C. Gallo, and R.E. Gallagher. 1977. Continuous growth and differentiation of human myeloid leukaemic cells in suspension culture. Nature 270: 347-349.

Collins, S., H. Coleman, and M. Groudine. 1987. Expression of $b c r$ and $b c r-a b l$ fusion transcripts in normal and leukemic cells. Mol. Cell. Biol. 7: 2870-2876.

Collins, S.J., K. Robertson, and L. Mueller. 1990. Retinoic acidinduced granulocytic differentiation of HL-60 myeloid leukemia cells is mediated directly through the retinoic acid receptor (RAR $\alpha$ ). Mol. Cell. Biol. 10: 2154-2161.

Cullum, M. and M. Zile. 1986. Quantitation of biological retinoids by high-pressure liquid chromatography: Primary internal standardization using tritiated retinoids. Anal. Biochem. 153: 23-32.

Damm, K., C.C. Thompson, and R.M. Evans. 1989. Protein encoded by v-erbA functions as a thyroid-hormone receptor antagonist. Nature 339: 593-597.

Davis, R., H. Weintraub, and A. Lassar. 1987. Expression of a single transfected cDNA converts fibroblasts to myoblasts. Cell 51: $987-1000$.

Denburg, J.A. 1992. Basophil and mast cell lineages in vitro and in vivo (review). Blood 79: 846-860.

DeRuyter, M.G., W. Lambert, and P. DeLunheer. 1979. Retinoic acid: An endogenous compound of human blood. Unequivocal demonstration of endogenous retinoic acid in normal physiological conditions. Anal. Biochem. 98: 402-409.

Desbois, C., D. Aubert, C. Legrand, B. Pain, and J. Samarut. 1991. A novel mechanism of action for v-erbA: Abrogation of the inactivation of transcription factor AP-1 by retinoic acid and thyroid hormone receptors. Cell 67: 731-740.

de The, H., A. Marchio, P. Tiollais, and A. Dejean. 1989. Differential expression and ligand regulation of the retinoic acid receptor $\alpha$ and $\beta$ genes. EMBO I. 8: 429-433.

de The, H., M. Vivanco-Ruiz, P. Tiollais, H. Stunnenberg, and A. Dejean. 1990a. Identification of a retinoic acid responsive element in the retinoic acid receptor $\beta$ gene. Nature 343: $177-180$.

de The, H., C. Chomienne, M. Lanotte, L. Degos, and A. Dejean. 1990b. The $t(15 ; 17)$ translocation of acute promyelocytic leukemia fuses the retinoic acid receptor $\alpha$ gene to a novel transcribed locus. Nature 347: 558-561.

de The, H., C. Lavau, A. Marchio, C. Chomienne, L. Degos, and A. Dejean. 1991. The PML-RAR $\alpha$ fusion mRNA generated by the $t(15 ; 17)$ translocation in acute promyelocytic leukemia encodes a functionally altered RAR. Cell 66: 675-684.

Evans, R. 1988. The steroid and thyroid hormone receptor superfamily. Science 240: 889-895.

Gallagher, R., F. Said, I. Pua, P. Papenhausen, E. Paietta, and P. 
Wiernik. 1989. Expression of retinoic acid receptor- $\alpha$ in human leukemia cells with variable responsiveness to retinoic acid. Leukemia 3: 789-795.

Geballe, A., R. Spate, and E. Mocarski. 1986. A cis-acting element within the $5^{\prime}$ leader of a cytomegalovirus beta transcript determines kinetic class. Cell 46: 865-876.

Giguere, V., E. Ong, P. Segui, and R. Evans. 1987. Identification of a receptor for the morphogen retinoic acid. Nature 330: $624-629$.

Herskowitz, I. 1987. Functional inactivation of genes by dominant negative mutations. Nature 329: 219-222.

Hirsch, S. and S. Gordon. 1983. Polymorphic expression of a neutrophil differentiation antigen revealed by monoclonal antibody 7/4. Immunogenetics 18: 229-239.

Hong, W.K., S.M. Lippman, L. Itri, D.D. Karp, J.S. Lee, R.M. Byers, S.P. Schatz, A.M. Kramer, R. Lotan, L.J. Peters, I.W. Dimery, B.W. Brown, and H. Goepfert. 1990. Prevention of second primary tumors with isotretinoin in squamous cell carcinoma of the head and neck. New Engl. I. Med. 323: 795801.

Huang, M.-E., Y.-C. Ye, S.-R. Chen, J.-R. Chai, J.-X. Lu, L. Zhoa, H.-T. Gu, and Z.-Y. Wang. 1988. Use of all-trans retinoic acid in the treatment of acute promyelocytic leukemia. Blood 72: $567-572$.

Just, U., C. Stocking, E. Spooncer, T.M. Dexter, and W. Ostertag. 1991. Expression of the GM-CSF gene after retroviral transfer in hematopoietic stem cell line induces synchronous granulocyte-macrophage differentiation. Cell 64: 1163-1173.

Kakizuka, A., W. Miller, K. Umesono, R. Warrell, S. Frankel, V. Murty, E. Dmitrovsky, and R. Evans. 1991. Chromosomal translocation $t(15 ; 17)$ in human acute promyelocytic leukemia fuses RAR $\alpha$ with a novel putative transcription factor PML. Cell 66: 663-674.

Kliewer, S., K. Umesono, D.J. Mangelsdorf, and R.M. Evans. 1992. Retinoid X receptor interacts with nuclear receptors in retinoic acid, thyroid hormone and vitamin D3 signalling. Nature 355: 446-449.

Largman, C., K. Detmer, J. Corral, F. Hack, and H. Lawrence. 1989. Expression of retinoic acid receptor alpha mRNA in human leukemic cells. Blood $\alpha 74$ : 99-102.

Lavin, T. N., J.D. Baxter, and S. Horita. 1988. The thyroid hormone receptor binds to multiple domains of the rat growth hormone 5'-flanking sequence. J. Biol. Chem. 163: 94189426.

Leid, M., P. Kastner, R. Lyons, H. Nakshatri, M. Saunders, T. Zacharewski, J.Y. Chen, A. Staub, and P. Chambon. 1992. Purification, cloning, and RXR identity of the HeLa cell factor with which RAR or TR heterodimerizes to bind target sequences efficiently. Cell 68: 377-395.

Lotan, R. 1980. Effects of vitamin A and its analogs (retinoids) on normal and neoplastic cells. Biochim. Biophys. Acta 605: 33-91.

Martin, D.I.K., L.I. Zon, G. Mutter, and S.H. Orkin. 1990. Expression of an erythroid transcription factor in megakaryocytic and mast cell lineages. Nature 344: 444-447.

Merriman, R. and J. Bertram. 1979. Reversible inhibition by retinoids of 3-methylcholanthrene-induced neoplastic transformation in C3H/10T clone 8 cells. Cancer Res. 39: 16611666.

Metzger, H., G. Alcaraz, R. Hohman, J. Kinet, V. Pribula, and R. Ovarto. 1986. The receptor with high affinity for immunoglobulin IgE. Annu. Rev. Immunol. 4: 419-470.

Miller, A.D. 1990. Retrovirus packaging cells. Hum. Gene Ther 1: 5-14.

Miller, A.D. and G.J. Rosman. 1989. Improved retroviral vectors for gene transfer and expression. Biotechniques 7: 980-990.

Riley, J.F. and G.B. West. 1953. The presence of histamine in tissue mast cells. J. Physiol. 120: 528-532.

Sambrook, J., E. Fritsch, and T. Maniatis. 1989. Molecular cloning: A laboratory manual. Cold Spring Harbor Laboratory Press, Cold Spring Harbor, New York.

Sap, J.A., A. Munoz, J. Schmitt, H. Stunnenberg, and B. Vennstrom. 1989. Repression of transcription mediated by a thyroid hormone response element by the v-erbA oncogene product. Nature 340: 242-244.

Simeone, A., D. Acampora, L. Arcioni, P. Andrews, E. Boncinelli, and F. Mavilio. 1990. Sequential activation of HOX2 homeobox genes by retinoic acid in human embryonal carcinoma cells. Nature 346: 763-766.

Spooncer, E., C. Heyworth, A. Dunn, and T.M. Dexter. 1986. Self-renewal and differentiation of interleukin-3-dependent multipotent stem cells are modulated by stromal cells and serum factors. Differentiation 31: 111-118.

Thaller, C. and G. Eichele. 1987. Identification and spatial distribution of retinoids in the developing chick limb buds. Nature 327: 625-628.

Thompson, H.L., D.D. Metcalfe, and J.-P. Kinet. 1990. Early expression of high affinity receptor for immunoglobulin E during differentiation of mouse mast cells and human basophils. J. Clin. Invest. 85: 1227-1233.

Tsai, S.-F., D. Martin, L. Zon, A. D'Andrea, G. Wong, and S. Orkin. 1989. Cloning of cDNA for the major DNA-binding protein of the erythroid lineage through expression in mammalian cells. Nature 339: 446-451.

Umesono, K., V. Giguere, C. Glass, M. Rosenfeld, and R. Evans. 1988. Retinoic acid and thyroid hormone induce gene expression through a common responsive element. Nature 336: 262-265.

Warrell, R., S. Frankel, W. Miller, D. Scheinberg, L. Itri, W. Hittelman, R. Vyas, M. Andreef, A. Tafuri, A. Jakubowski, J. Gabrilove, M. Gordon, and E. Dmitrovsky. 1991. Differentiation therapy of acute promyelocytic leukemia with tretinoin (all trans retinoic acid). New Engl. I. Med. 324: 13851393.

Yu, V.C., C. Delsert, B. Anderson, J.M. Holloway, O.V. Devary, A.M. Naar, S.Y. Kim, J.-M. Boutin, C.K. Glass, and M.G.Rosenfeld. 1992. RXR $\beta$ : A coregulator that enhances binding of retinoic acid, thyroid hormone, and vitamin $D$ receptors to their cognate response elements. Cell 67: 12511266.

Zelent, A., A. Krust, M. Petkovich, P. Kastner, and P. Chambon. 1989. Cloning of murine $\alpha$ and $\beta$ retinoic acid receptors and a novel receptor predominantly expressed in skin. Nature 339: 714-717.

Zenke, M., P. Kahn, C. Disela, B. Vennstrom, A. Leutz, K. Keegan, M. Hayman, H.-R. Choi, N. Yew, J.D. Engel, and H. Beug. 1988. v-erbA specifically suppresses transcription of the avian erythrocyte anion transporter (band 3) gene. Cell 52: 107-119.

Zenke, M., A. Munoz, J. Sap, B. Vennstrom, and H. Beug. 1990. $\mathrm{v}$-erbA oncogene activation entails the loss of hormone-dependent regulator activity of c-erbA. Cell 61: 1035-1049.

Zhang, X.-K. B. Hoffman, P. B.-V. Tran, G. Graupner, and M. Pfahl. 1992. Retinoid X receptor is an auxiliary protein for thyroid hormone and retinoic acid receptors. Nature 355: 441-446.

Zon, I.L., M.F. Gurish, R. Stevens, C. Mather, D.S. Reynolds, K.F. Austen, and S.H. Orkin. 1991. GATA-binding transcription factors in mast cells regulate the promoter of the mast cell carboxypeptidase A gene. J. Biol. Chem. 266: 2294822953. 


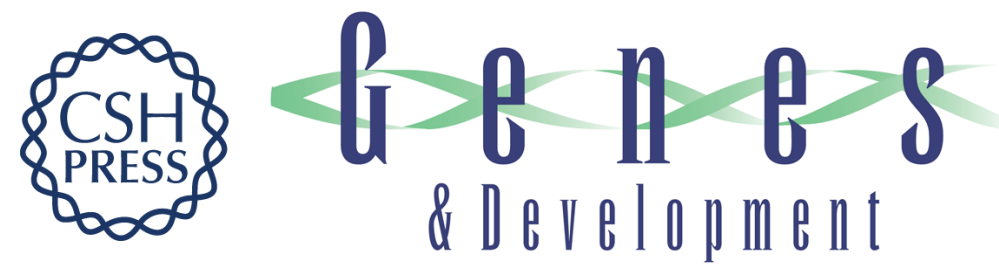

\section{A mutated retinoic acid receptor-alpha exhibiting dominant-negative activity alters the lineage development of a multipotent hematopoietic cell line.}

S Tsai, S Bartelmez, R Heyman, et al.

Genes Dev. 1992, 6:

Access the most recent version at doi:10.1101/gad.6.12a.2258

References This article cites 53 articles, 13 of which can be accessed free at:

http://genesdev.cshlp.org/content/6/12a/2258.full.html\#ref-list-1

License

Email Alerting

Service

Receive free email alerts when new articles cite this article - sign up in the box at the top right corner of the article or click here.

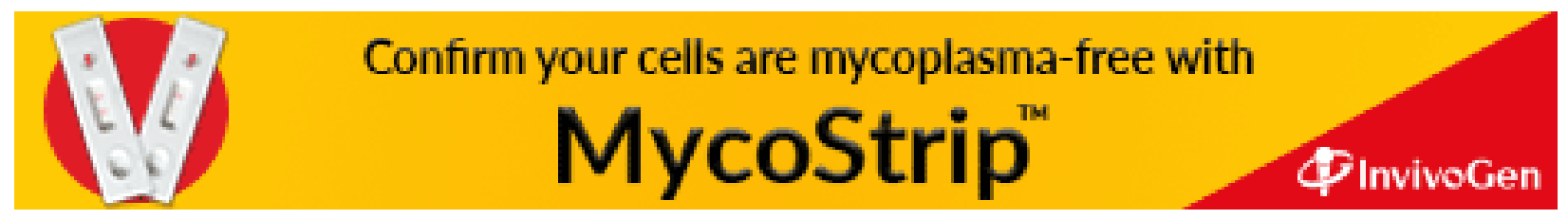

